\title{
Corrigendum
}

\section{Benefits of blood cell transplant cryopreservation with oxypolygelatine (Gelifundol) plasma substitute}

M Di Nicola, S Siena, M Bregni, N Belli, M Milanesi, PA Ruffini, F Malaffo, P Matteucci, F Ravagnani and AM Gianni

Bone Marrow Transplantation 1996; 18: 619-623

Since publication of the above paper the authors have notified us of two omissions. The name of Paola Matteucci was erroneously not included among the authors of the manuscript. The correct order of authors is given above. Also the acknowledgements section should have included the following sentence: PA Ruffini is supported by a fellowship from AIRC. The corrected acknowledgements section follows.

\section{Acknowledgements}

Study partly supported by grants from Associazione Italiana Ricerca Cancro (AIRC), Consiglio Nazionale Ricerche (CNR) 92.02329.PF39 and 92.02342.PF39, Amgen, Bristol-Myers Squibb, Immunex, and jointly by Sandoz and Schering-Plough. PA Ruffini is supported by a fellowship from Associazione Italiana Ricerca Cancro (AIRC). 